\title{
Detection of Low-Molecular-Weight Mast Cell-Activating Factors in Serum From Patients With Chronic Spontaneous Urticaria
}

\author{
Cugno $\mathrm{M}^{1}$, Tedeschi $\mathrm{A}^{2}$, Frossi $\mathrm{B}^{3}$, Bossi $\mathrm{F}^{4}$, Marzano AV ${ }^{5}$, Asero $\mathrm{R}^{6}$
}

'Medicina Interna, Dipartimento di Fisiopatologia Medico-Chirurgica e dei Trapianti, Università degli Studi di Milano, Fondazione IRCCS Ca' Granda, Ospedale Maggiore Policlinico, Milano, Italy

${ }^{2} \mathrm{SC}$ Medicina Interna a Indirizzo Pneumologico, AO Fatebenefratelli e Oftalmico, Milano, Italy

${ }^{3}$ Dipartmento di Scienze e Tecnologie Biomediche, Università di Udine, Udine, Italy

${ }^{4}$ Dipartmento di Scienze Mediche, Chirurgiche e della Salute, Università di Trieste, Ospedale Universitario di

Cattinara, Trieste, Italy

${ }^{5}$ Unità Operativa di Dermatologia, Dipartimento di Fisiopatologia Medico-Chirurgica e dei Trapianti, Università degli Studi di Milano, Fondazione IRCCS Ca' Granda, Ospedale Maggiore Policlinico, Milano, Italy

${ }^{6}$ Ambulatorio di Allergologia, Clinica San Carlo, Paderno Dugnano, Italy

J Investig Allergol Clin Immunol 2016; Vol. 26(5): 310-313

doi: 10.18176/jiaci.0051

\section{Abstract}

Background: Functionally active autoantibodies to IgE and to the high-affinity lgE receptor (FcERI) can be detected in serum in about $40 \%$ of patients with chronic spontaneous urticaria (CSU). Recent studies showed that serum from patients with CSU can induce activation of mast cells, irrespective of whether they carry high-affinity lgE receptors.

Objective: To evaluate mast cell activation induced by factors in the serum of CSU patients with a molecular weight lower than that of autoantibodies.

Methods: Eight CSU patients and 5 healthy controls were evaluated. Whole serum and serum fractionated at 100, 50, and 30 kDa were used to stimulate in vitro LAD2 mast cells. The enzymatic activity of $\beta$-hexosaminidase was evaluated in supernatants and cell pellets as a measure of mast cell degranulation.

Results: Mean (SEM) release of mast cell $\beta$-hexosaminidase induced by whole serum from CSU patients was higher than that induced by serum from the healthy controls (14.4 [2.7\%] vs 5.1 [2.4\%]; $P=.027)$. In addition, serum fractions below $100 \mathrm{kDa}$ and below $50 \mathrm{kDa}$ from CSU patients induced mast cell degranulation that was significantly higher than that induced by the corresponding fractions in sera from healthy controls (10.2\% [1.4\%] vs 3.8\% [1.9\%] [P=.024] and $10.1 \%[1.2 \%]$ vs 3.9\% [1.7\%] $[P=.012]$, respectively). In 4 CSU patients, we evaluated serum fractions $<30 \mathrm{kDa}$, which retained their capacity to activate mast cells $(11.0 \%[0.7 \%])$.

Conclusions: This study shows that sera from CSU patients may contain low-molecular-weight mast cell-activating factors other than autoantibodies. These factors could be an additional mechanism contributing to the pathogenesis of CSU.

Key words: Chronic urticaria. Pathogenesis. Histamine-releasing factors. Mast cells.

\section{Resumen}

Introducción: Los autoanticuerpos IgE funcionalmente activos y los receptores de alta afinidad para la lgE (FcERI) pueden ser detectados en el suero de aproximadamente un 40\% de los pacientes con urticaria crónica espontánea (UCE). Estudios recientes muestran que el suero de estos pacientes puede inducir activación de mastocitos con o sin receptores de alta afinidad para la lgE.

Objetivo: El objetivo de este estudio fue evaluar la actividad de los factores séricos de los sueros de pacientes con UCE con un peso molecular inferior al de los autoanticuerpos.

Métodos: Para ello se estudiaron 8 pacientes con UCE y 5 controles sanos. El suero completo de cada uno de ellos y el fraccionado a 100,50 y 30 kDA se utilizó para estimular in vitro mastocitos LAD2. La actividad enzimática de la $\beta$-hexosaminidasa se determinó en los sobrenadantes y en el botón celular con el fin de cuantificar la degranulación mastocitaria. 
Resultados: En cuanto a los resultados obtenidos se observó una liberación de $\beta$-hexosaminidasa mastocitaria inducida por los sueros completos de los pacientes con UCE $(14,4 \pm 2,7 \%$, media \pm EE de la media) significativamente mayor que la inducida por sueros de controles sanos $(5,1 \pm 2,4 \% ; p=0,027)$. Así mismo, las fracciones séricas inferiores a 100 kDa e inferiores a 50 kDa de los pacientes con UCE indujeron degranulación mastocitaria significativamente superior a la inducida por las fracciones correspondientes de sueros controles $(10,2 \pm 1,4 \%$ vs $3,8 \pm 1,9 \%[p=0,024]$ and $10,1 \pm 1,2 \%$ vs 3,9 $9 \pm 1,7 \%[p=0,012]$, respectivamente). En 4 pacientes con UCE observamos que las fracciones inferiores a $30 \mathrm{kDa}$ mantenían la capacidad de activar a los mastocitos $(11,0 \pm 0,7 \%)$.

Conclusiones: En conclusión, este estudio muestra que el suero de los pacientes con UCE puede contener factores de bajo peso molecular diferentes a los autoanticuerpos que son capaces de activar a los mastocitos. Este hallazgo podría contribuir a conocer los mecanismos de la patogénesis de la UCE.

Palabras clave: Urticaria crónica. Patogénesis. Factores liberadores de histamina. Mastocitos.

\section{Introduction}

Chronic spontaneous urticaria (CSU) is characterized by recurrent eruption of itchy wheals with or without angioedema for more than 6 weeks. More than 20 years ago, functionally active autoantibodies to $\operatorname{IgE}$ and to the high-affinity IgE receptor (FceRI) were first detected in the sera of CSU patients [1-3], and this appeared to be the most reasonable explanation for the pathogenesis of CSU. However, functional autoantibodies can be detected in approximately $40 \%$ of cases of CSU [2,3], and some sera from CSU patients lacking autoantibodies to FceRI are able to induce histamine release from basophils cultured in vitro [4]. Furthermore, in recent years, Eckman et al [5] demonstrated that there is no strict association between FceRI autoantibodies and the histamine-releasing activity of serum from CSU patients. About $50 \%$ of CSU patients, a proportion that includes all those with functionally active circulating autoantibodies to FceRI and IgE, are "autoreactive," that is, intradermal injection of autologous serum (autologous serum skin test [ASST]) elicits a wheal-and-flare reaction [6]. However, the result of the ASST does not always correlate with the result of the in vitro assay with histamine-releasing autoantibodies. Fagiolo et al [7] found that serum from CSU patients retains the ability to induce a wheal-and-flare reaction upon intradermal injection of autologous serum even after depletion of IgG. Although isolated IgG anti-IgE receptor was shown to be responsible for the induction of histamine release from basophils, and the residual IgG-depleted serum was shown to be negative [8], overall experimental findings suggest the possible involvement of factors other than autoantibodies, both in the autoreactive state detected by ASST and in the pathogenesis of CSU. Recently, we found that serum from CSU patients induced degranulation of mast cells lacking the high-affinity IgE receptor, thus showing that degranulating factors may also act through different pathways [9]. In the present study, we tried to further characterize mast cell-activating factors by fractionation of sera from CSU patients. The rationale of our approach is that serum fractionation makes it possible to detect the molecular weight range of mast cell-activating factors and to investigate whether or not these factors are autoantibodies.

\section{Methods}

We studied sera from 8 patients with CSU (5 women and 3 men; age range, 23-55 years) diagnosed according to generally accepted criteria [10] and from 5 healthy controls (3 women and 2 men; age range, 25-50 years). All patients underwent the ASST as previously described [6]. All patients and controls gave their informed consent to blood collection for research purposes, and the study was conducted in accordance with the Declaration of Helsinki. Whole sera were filtered at $4^{\circ} \mathrm{C}$ through membranes with a cutoff of 100 and $50 \mathrm{kDa}$ (Amicon Inc). Samples of whole sera as well as of fractions $<100 \mathrm{kDa}$ and $<50 \mathrm{kDa}$ were frozen until use. In subsequent experiments, sera from 4 of the CSU patients (2 ASST-positive, 2 ASST-negative) were also filtered with a cutoff of $30 \mathrm{kDa}$. Whole serum and serum fractions were used for in vitro stimulation of mast cells from the Laboratory of Allergic Diseases 2 cell line (LAD2, kindly provided by Dr A Kirshenbaum, NIH, Bethesda, Maryland, USA), which closely

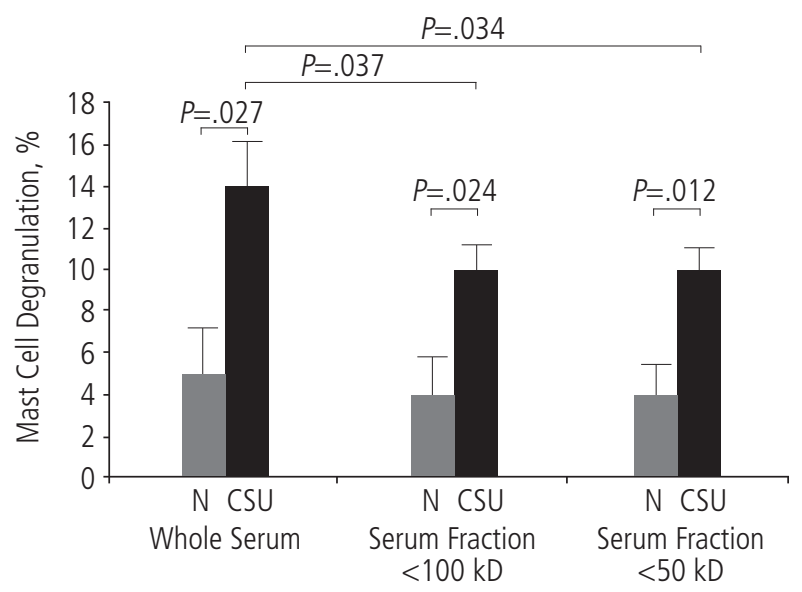

Figure 1. Mast cell degranulation induced by serum and serum fractions $(<100 \mathrm{kDa}$ and $<50 \mathrm{kDa}$ ) from 8 patients with chronic spontaneous urticaria (CSU) and 5 normal controls (N). Results are expressed as mean (bars) and standard error of the mean (whiskers) of the percentage of $\beta$-hexosaminidase release over total $\beta$-hexosaminidase content. The statistical analysis was based on an analysis of variance and $t$ test for unpaired data. 
resemble CD34+-derived human mast cells. LAD2 cells were suspended at $2 \times 10^{6} / \mathrm{mL}$ in Tyrode/BSA $0.05 \%$ solution and incubated with whole serum and serum fractions from patients or with serum from healthy donors $(1: 100)$ for 30 minutes. The enzymatic activity of $\beta$-hexosaminidase in supernatants and in the cell pellets after solubilization was evaluated using a chromogenic method described elsewhere [9]. The result was expressed as the proportion of released $\beta$-hexosaminidase over total $\beta$-hexosaminidase and indicated the percentage of mast cell degranulation. A positive control was obtained by cell stimulation with $1 \mu \mathrm{M}$ ionomycin for 30 minutes. The $\mathrm{t}$ test for unpaired values was used to assess the statistical significance of the differences between groups. Data were analyzed using SPSS Statistics for Windows, version 22.00 (IBM Corp). Statistical significance was set at $P<.05$.

\section{Results}

The results of the degranulation experiments are shown in Figure 1. Mean (SEM) degranulation induced by whole serum from the $8 \mathrm{CSU}$ patients was significantly higher than that induced by the 5 control sera $(14.4 \%$ [2.7\%] vs $5.1 \%$ $[2.4 \%] ; P=.027)$. In addition, serum fractions $<100 \mathrm{kDa}$ and $<50 \mathrm{kDa}$ from CSU patients induced mast cell degranulation that was significantly higher than that induced by the corresponding fractions from control sera $(10.2 \%[1.4 \%]$ vs $3.8 \%[1.9 \%][P=.024]$ and $10.1 \%[1.2 \%]$ vs $3.9[1.7 \%]$ $[P=.012]$, respectively). The average $\beta$-hexosaminidasereleasing activity of CSU serum fractions was lower than that of whole serum (Figure 1). Owing to limited sample supply, we were only able to test mast cell degranulation of serum samples undergoing $30-\mathrm{kDa}$ fractionation in a subgroup of 4 CSU patients. As shown in Figure 2, these serum fractions were constantly able to induce LAD2 mast cell degranulation $(11 \%[0.7 \%])$ compared with those of the negative and positive controls, ie, phosphate-buffered saline $(4.0 \%[0.6 \%])$

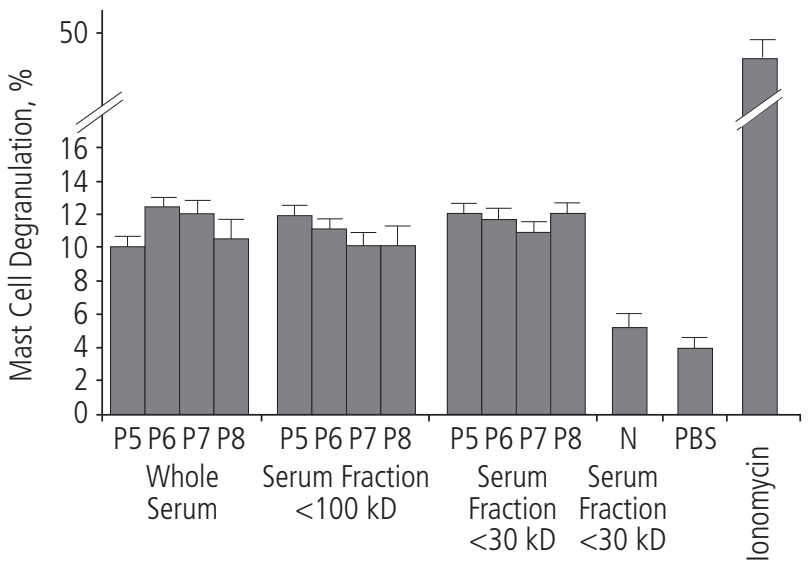

Figure 2. Mast cell degranulation induced by serum fractions $<30 \mathrm{kDa}$ from 4 patients with chronic spontaneous urticaria (patients $[P] 5,6,7$ and 8) and from 5 normal controls (N), phosphate-buffered saline (PBS) and ionomycin. Results are expressed as mean (bars) and standard error of the mean (whiskers) for patients (3 replicates), PBS (5 replicates) ionomycin (5 replicates), and 5 healthy controls. and ionomycin (47.3\% [2.7\%]). No significant differences were observed between ASST-positive patients $(n=4)$ and ASST-negative patients $(n=4)$. The Table shows the results of the ASST and $\beta$-hexosaminidase release from LAD2 cells stimulated with whole serum and serum fractions with a molecular weight $>100 \mathrm{kDa}$ and $<50 \mathrm{kDa}$ from 8 patients with CSU and 5 healthy controls.

\section{Discussion}

Some years ago we demonstrated that serum from patients with CSU can degranulate mast cells through a mechanism that is independent of FceRI and, hence, of both $\operatorname{IgE}$ and $\operatorname{IgG}$ [9]. This finding was in keeping with the observation that most patients with CSU lack autoantibodies to the mast cell FceRI and to IgE. In the present study, we aimed to confirm this finding and tried to better characterize the factor(s) involved in mast cell degranulation. On average, whole serum was able to induce more intense degranulation than serum fractions, probably owing to the presence of autoantibodies to the high-affinity $\operatorname{IgE}$ receptor or to $\mathrm{IgE}$ in the $>100-\mathrm{kDa}$ serum fraction of some patients $(1-4,6)$. However, interestingly, all the sera that we examined also contained low-molecularweight circulating mast cell-activating factor(s). In some cases, such as the 4 sera for whom the $<30-k D a$ fraction was available, $\beta$-hexosaminidase release from LAD2 cells was induced to the same extent by low-molecular-weight fractions as by whole serum, thus suggesting the presence of low-molecular-weight mast cell-activating factors. These observations might explain the occurrence of histamine release, and hence of CSU, in patients whose serum lacks functional autoantibodies specific for the high-affinity $\operatorname{IgE}$ receptor or for IgE. Moreover, these findings are in keeping with those of Eckman et al [5], who found that the presence of autoantibodies was not correlated with histamine release from cultured cells. Another interesting finding is that circulating

Table. Results of Autologous Serum Skin Test (ASST) and Mast Cell Degranulation Induced by Sera and Serum fractions (Mw, >100 kDa and $<50 \mathrm{kDa}$ ) From 8 Patients With Chronic Spontaneous Urticaria and 5 Healthy Controls ${ }^{a}$

\begin{tabular}{lcccc}
\hline Patient & ASST, mm & Serum & $>100 \mathrm{kDa}$ & $<50 \mathrm{kDa}$ \\
\hline 1 & Negative & 5.53 & 2.92 & 5.00 \\
2 & $8 \mathrm{~mm}$ & 11.86 & 8.30 & 6.00 \\
3 & $8 \mathrm{~mm}$ & 24.51 & 9.70 & 13.00 \\
4 & Negative & 28.07 & 8.20 & 15.00 \\
5 & Negative & 10.09 & 3.90 & 11.00 \\
6 & $4 \mathrm{~mm}$ & 12.54 & 5.30 & 9.00 \\
7 & $4 \mathrm{~mm}$ & 12.20 & 6.20 & 11.00 \\
8 & Negative & 10.30 & 4.60 & 11.00 \\
Normal & & & & \\
controls $(\mathrm{n}=5)$ & Negative & $5.1(2.4)$ & $1.1(0.1)$ & $3.9(1.7)$ \\
\hline
\end{tabular}

axpressed as percentage of $\beta$-hexosaminidase release over total B-hexosaminidase content. 
low-molecular-weight $\beta$-hexosaminidase-releasing factor(s) is present in sera from both ASST-positive and ASST-negative CSU patients. In this sense, our findings differ from those of a very old study in which Grattan et al [11] were able to detect a low-molecular-weight serum factor causing a wheal-and-flare skin reaction upon intradermal injection. In the light of our findings and those of other studies [5], factors unrelated to autoantibodies to the high-affinity $\operatorname{IgE}$ receptor or to $\operatorname{IgE}$ and apparently unrelated to "autoreactivity" (ie, positive ASST result) also seem to be involved in the pathogenesis of CSU. The nature of the low-molecular-weight factor(s) inducing mast cell degranulation that we detected remains unclear, although we intend to characterize these factors in the near future. We cannot exclude a possible relationship with $\mathrm{C} 5 \mathrm{a}$ or other cell-activating chemokines. However, the possibility that this factor corresponds to $\mathrm{C} 5 \mathrm{a}$ in all cases seems questionable, as the complement fraction is formed following complement activation by anti-FceRI autoantibodies (12), whose presence is generally associated with a clearly positive ASST result (6). We also detected mast cell-activating fractions in ASSTnegative patients.

It could prove interesting to evaluate the effect of anti-C5a on mast cell degranulation induced by sera from ASST-positive CSU patients. In conclusion, circulating mast cell-activating factor(s) with a molecular weight $<30 \mathrm{kD}$ can be detected in patients with CSU. The presence of these factors is independent of autoantibodies and autoreactivity and might contribute to the pathogenesis of CSU.

\section{Funding}

The authors declare that no funding was received for the present study.

\section{Conflicts of Interest}

The authors declare that they have no conflicts of interest.

\section{References}

1. Gruber BL, Baeza ML, Marchese MJ, Agnello V, Kaplan AP. Prevalence and functional role of anti-lgE autoantibodies in urticarial syndromes. J Invest Dermatol. 1988;90:213-7.

2. Grattan CEH, Francis DM, Hide M, Greaves MW. Detection of circulating histamine releasing autoantibodies with functional properties of anti IgE in chronic urticaria. Clin Exp Allergy. 1991;21:695-704.

3. Hide M, Francis DM, Grattan CEH, Hakimi J, Kochan JP, Greaves MW. Autoantibodies against the high-affinity lgE receptor as a cause of histamine release in chronic urticaria. N Engl J Med. 1993;328:1599-604.

4. Ferrer M, Kinet J-P, KaplanAP. Comparative studies of functional and binding assays for $\lg G$ anti-FceRl $\alpha$ (alpha-subunit) in chronic urticaria. J Allergy Clin Immunol. 1998;101:672-6.
5. Eckman JA, Hamilton RG, Saini SS. Independent evaluation of a commercial test for "autoimmune" urticaria in normal and chronic urticaria subjects. J Invest Dermatol. 2009;129:15846.

6. Asero R, Tedeschi A, Lorini M, Salimbeni R, Zanoletti T, Miadonna A. Chronic urticaria: novel clinical and serological aspects. Clin Exp Allergy. 2001;31:1105-10.

7. Fagiolo U, Cancian M, Bertollo L, Peserico A, Amadori A. Inhibitory effect of heparin on skin reactivity to autologous serum in chronic idiopathic urticaria. J Allergy Clin Immunol. 1999;103:1143-7.

8. Kikuchi Y, Kaplan AP. Mechanisms of autoimmune activation of basophils in chronic urticaria. J Allergy Clin Immunol. 2001;107:1056-62.

9. Bossi F, Frossi B, Radillo O, Cugno M, Tedeschi A, Riboldi P, Asero R, Tedesco F, Pucillo C. Mast cells are critically involved in serum-mediated vascular leakage in chronic urticaria beyond high-affinity lgE receptor stimulation. Allergy. 2011;66:153845.

10. Zuberbier T, Aberer W, Asero R, Bindslev-Jensen C, Brzoza Z, Canonica GW, Church MK, Ensina LF, Giménez-Arnau A, Godse K, Gonçalo M, Grattan C, Hebert J, Hide M, Kaplan A, Kapp A, Abdul Latiff AH, Mathelier-Fusade P, Metz M, Nast A, Saini SS, Sánchez-Borges $M$, Schmid-Grendelmeier $P_{1}$, Simons FE, Staubach P, Sussman G, Toubi E, Vena GA, Wedi B, Zhu $\mathrm{XJ}$, Maurer M; European Academy of Allergy and Clinical Immunology; Global Allergy and Asthma European Network; European Dermatology Forum; World Allergy Organization. The EAACI/GA(2)LEN/EDF/WAO Guideline for the definition, classification, diagnosis, and management of urticaria: the 2013 revision and update. Allergy. 2014;69:868-87.

11. Grattan CE, Hamon CG, Cowan MA, Leeming RJ. Preliminary identification of a low molecular weight serological mediator in chronic idiopathic urticaria. Br J Dermatol. 1988;119:17983.

12. Ferrer M, Nakazawa K, Kaplan AP. Complement dependence of histamine release in chronic urticaria. J Allergy Clin Immunol. 1999;104:169-72.

Manuscript received October 19, 2015; accepted for publication January 7, 2016.

\section{Riccardo Asero}

Ambulatorio di Allergologia, Clinica San Carlo

Via Ospedale 21

20037 Paderno Dugnano (MI)

Italy

E-mail: r.asero@libero.it 